\title{
2
}

\section{The French exception: The French nuclear power industry and its influence on political plans to transition to a new energy system}

\section{Christina Stuart}

\begin{abstract}
The Fukushima accident was a turning point for French energy policy, as it prompted the country to put forth legislation to reduce the share of nuclear power and accelerate renewable energy growth. Even so, France's nuclear fleet remains intact and dominates the French energy sector with powerful political momentum. An explanation and outlook for the evident tension between the two realities is the goal of this research. By first examining how the French nuclear industry came to be so exceptionally powerful, the industry's response to environmental, safety, and economic concerns is analysed. An outlook for the French nuclear industry within a new political framework is ultimately proposed. Based on a sociopolitical analysis, the nuclear industry currently overrides environmental and climate concerns by putting forward its low-carbon technology. The industry also controls safety concerns at the cost of extensive safety investments. However, this research shows that the finances that are currently keeping the industry afloat are ultimately creating an unstable economic situation. The balance of power between energy transition policy and nuclear industry growth is a question of economics over politics.
\end{abstract}




\section{Introduction}

In August 2015, former President François Hollande of France passed the Energy Transition for Green Growth Law (Energy Transition Law), which aims to reduce the share of nuclear generation in the national electricity mix. This unprecedented energy policy change commits the country to a suite of ambitious environmentally friendly targets, including reducing the share of nuclear electricity generation from 76.3 per cent (RTE 2016) to 50 per cent by 2025, and increasing the share of renewable electricity generation up to 40 per cent by 2030 (by increasing the total renewable energy share to 32 per cent). Whilst the objectives pertaining to greenhouse gas emission reductions and renewable energy generation are generally accepted, the legislated rapid decrease in the nuclear share remains controversial. How exactly these concrete energy transition targets will be met is unclear. According to the French Court of Audit, the nuclear industry would have to shut down seven to 20 reactors by 2025 , if electricity consumption and export levels remain stable. However, two years since the law was passed, Électricité de France (EDF), the electricity utility monopoly, has still not shut down its oldest, most unstable, and internationally contested nuclear plant in Fessenheim, at the border with Germany.

There is evident conflict and tension between, on the one hand, France's plans to transition to a new energy system that is less reliant on nuclear power and, on the other hand, the ease with which the French industry is refusing to implement these plans. To understand this disconnect, one has to recognise France's exceptional nuclear industry and powerful nuclear lobby. French nuclear power is exceptional as it has an industrial configuration inseparable from political power, it is the nervous system of the current centralised state, and it is so ingrained and established in French culture that this is the first time that it is being truly put into question. Due to this exceptional configuration, France's nuclear fleet is the second largest in the world after the United States' fleet, and the leading country in terms of the greatest share of nuclear generation in the national electricity mix. With 58 reactors accounting for 77 per cent of France's electricity generation, France relies on nuclear power more than any other country in the world. 
The international literature on nuclear energy generation exposes a recent trend for nuclear decline (Schneider et al. 2016). Even the projections by the International Atomic Energy Agency (IAEA) on nuclear expansion are being updated each year to consider both the consequences of ageing reactors and their corresponding closures, as well as a reduction in the rate of new nuclear reactor builds (IAEA 2014/2015). Even though the reasons for this global decline are complex and vary in nature between countries, there is clearly a global transition to a new energy paradigm. This new paradigm goes beyond an increase in renewable energy production and the slowing down of fossil fuel and nuclear energy growth. Energy sustainability policy is now being more directly driven by security of supply and the environment (including climate change). In contrast to the international literature, the French literature on nuclear energy generation is much less forward-looking and predominantly focuses on analysing the nuclear industry's historic decisions (Topçu 2013). As a consequence, there is no consensus on how French nuclear power is developing. In fact, whereas the international literature points to a struggling French nuclear industry, the French projections are optimistic and view the industry as an essential energy asset for low-carbon growth. A knowledge gap exists around how to reconcile how France is reacting to conflicting views on nuclear power.

In this chapter, I articulate why there is this conflict between the current state of affairs in France and international and national policies, as well as expose how this situation is developing within the context of a global energy system transition. More completely, the aims of this chapter are to explain how the French nuclear industry is an exception compared to other nuclear industries, and to understand to what extent the French nuclear industry's exceptional status might influence the outlook of France's energy system. Could the French nuclear establishment have enough power to resist current political objectives to reduce the share of nuclear and favour renewables? In an initial section, I discuss how the French nuclear industry has historically dictated energy policy and created a strong industrial configuration resistant to nuclear decline trends. In a second section, I address the role that nuclear has to play in the global environment and climate policy setting. A third section focuses on the French nuclear industry's strategy to mitigate nuclear safety risk aversion. Finally, the chapter concludes with an economic analysis of the French nuclear industry, questioning the extent to which it may remain politically influential. 


\section{Development of the French nuclear industry}

Before beginning to analyse the balance of power between the nuclear industry and French policies, one has to understand what makes the French nuclear industry so exceptional. For this, one has to go back to the explosive birth and introduction of nuclear technology into France. There are many elements that contribute to the success story of France's nuclear industry. I develop three of these, each of which has led to the political strength of the nuclear establishment. The first essential contributing factor to this success story is the nuclear industry's military origin. Second, the main actors that make up this industry are closely interlinked with each other and the government. Third, the French economy has grown to rely on its nuclear export capacity.

The 'dissuasive weapon' (l'arme de dissuasion) was the name given to nuclear fission technology by French President Charles De Gaulle and father of France's grandes programmes. After the Second World War, and in response to the successful tests of the first Soviet atomic bombs, Europe both feared and respected the power of nuclear fission technology. In 1952, the European Defence Community Project designed a treaty to protect member states from nuclear threats during the Cold War. Six member states including France agreed upon this treaty, which notably included a clause prohibiting all signatories of being in possession of an atomic bomb. However, after the defeat of the French Union by the Viet Minh during the first Indochina war in 1954, General De Gaulle made the decision to begin producing atomic weapons, in the name of national defence. Thus, France officially rejected the treaty.

In 1958, when De Gaulle became president of the fifth Constitution, he was appointed, by definition, head of the army and therefore of nuclear arms control. Complete control over such a powerful and potentially dangerous technology by one person was, however, difficult for the public to accept. To legitimise possessing such power, De Gaulle announced a referendum in 1962 resulting in a modification of the presidential election procedure, which replaced indirect suffrage with a direct universal suffrage system. By making his presidency a democratic statement, De Gaulle gave 
legitimacy to his nuclear arms control (Chantebout 1986). ${ }^{1}$ De Gaulle viewed nuclear as much more than a military strategy; it was at the heart of his national independence policy strategy. For him, military nuclear was not enough and civil nuclear power became his solution to ensuring conformity with Article 5 of the French Constitution, which states that the president is the 'guarantor of national independence'. The paradigm shift during the 1960s from nuclear as a military strategy to a civil commodity marked a historic turning point in French history.

National energy independence was translated as independence from fossil fuel imports, a political strategy used to push civil nuclear power generation. Independence especially from North American oil imports was paramount. In fact, France left the North Atlantic Treaty Organization (NATO) in 1966, symbolising its independence. Ironically, as soon as De Gaulle was no longer president (1969), the American pressurised water reactor (PWR) design was imported and used for new builds from then on as they were cheaper than the French Uranium Naturel Graphite Gaz (UNGG) reactor design (Reuss 2007: 68). Of course, complete 'energy independence' was an exaggeration, as nuclear only covers electricity generation. Oil and gasoline imports for transport were hardly affected and unavoidable.

EDF commenced construction of pilot nuclear reactor projects in the 1960s, whilst a gradual shift towards electrifying all possible energy flows began. Military funding conveniently supported the investment in civil nuclear and the continuation of these pilot projects. Most often, the reasons given to explain France's transition to civil nuclear power and to justify colossal nuclear investments made by the French government are linked to the oil crisis of 1973 . However, to remain chronologically coherent, the civil nuclear investments have to be considered in conjunction with military ambitions during the 1970s Arab-Israeli conflicts. In May 1973, before the oil crisis, Prime Minister Pierre Messmer, during an interministerial committee, had already announced that France would accelerate his initial plan for 8,000 megawatts (MW), to be built between 1972 and 1977, to 13,000 MW of nuclear capacity (INA 1975).

1 'It is therefore impossible not to draw a comparison between the development of the first French atomic weapons and the constitutional reform of 1962 on the election of the president by direct universal suffrage. It is certain that only a legal personality who enjoys the full legitimacy conferred to himself/herself by direct election by the people can find in himself/herself the moral strength necessary to decide upon the use of such a lethal device' (Chantebout 1986). 
Only a few months later, the oil crisis shocked economies worldwide, giving civil nuclear power generation the perfect reason to exist and flourish. Offering energy independence and military defence, nuclear reactors took on a construction speed not seen in any other country. Although the oil crisis happened almost simultaneously with the decision to accelerate the nuclear electrification of France, it is important to note that before the crisis the civil nuclear plan had already been formulated. This culminated in Prime Minister Messmer's 1974 famous plan: 'all nuclear' (le tout-nucléaire). The first phase of the Messmer Plan was to construct 13 nuclear reactors, each of $900 \mathrm{MW}$ in capacity, in two years. Ten years later, 50 Westinghouse PWRs were under construction all over the country. ${ }^{2}$ As for the French population, the justification for the civil nuclear investment came down to promising cheap national electricity. ${ }^{3}$

Today's nuclear fleet was constructed in three main phases: CP0 (Contract Programme 0), CP1, and CP2 were constructed between 1971 and 1982, P4 and P' 4 between 1977 and 1986, and the N4 reactor series was constructed between 1984 and 1993 (see Table 2.1).

Table 2.1 The three phases of construction of the current French nuclear reactor fleet

\begin{tabular}{|l|c|c|c|c|}
\hline Reactor series & Construction dates & \multicolumn{2}{|c|}{ Number of reactors } & Class in MWe \\
\hline CP0 & $1971-74$ & 6 & \multirow{2}{*}{34} & 900 \\
\cline { 1 - 3 } CP1 & $1974-81$ & 18 & & 900 \\
\hline CP2 & $1976-82$ & 10 & & 900 \\
\hline P4 & $1977-80$ & 8 & 20 & 1300 \\
\hline P'4 & $1980-86$ & 12 & & 1300 \\
\hline N4 & $1984-93$ & 4 & 4 & 1450 \\
\hline Total & $1971-93$ & & 58 & $\begin{array}{c}\text { Total net capacity } \\
\text { in MWe: 63,130 }\end{array}$ \\
\hline
\end{tabular}

MWe = megawatt electric

Source: Based on Brottes and Baupin (2014).

2 Although six nuclear reactors of French UNGG design had been built (at the Chinon, Saint Laurent des Eaux, and Bugey sites), the decision was made to switch to the cheaper American PWR model. The Alternative Energies and Atomic Energy Commission (Commissariat à l'énergie atomique et aux énergies alternatives, CEA) was strongly supportive of the UNGG model in contrast to EDF, which supported the Westinghouse model.

3 At the time, France's electricity was mainly derived from imported oil power plants. Hence, electricity was very expensive considering the oil crisis. 
Although the civil 'all nuclear' plan was not fully realised, almost 80 per cent of France's electricity production is nuclear-based and even today not entirely disconnected from military interest. In addition to the electronuclear reactors, uranium enrichment facilities such as at the Tricastin site provide joint military and civil services. Indeed, as well as being part of France's fuel recycling capacity, these facilities enable plutonium extraction. Although the military origin is part of the fleet's grand history, the military connection lingers.

The same actors that enabled the development of the current nuclear fleet still exist today-more than exist, they are still at the heart of the nuclear industry in France. Three main actors constitute this industrial configuration. First, EDF is France's monopoly electricity utility. In 1946, it was decided that this company be a nationalised integrated monopoly to avoid competition and benefit from state support. Unlike in the United States or the United Kingdom where many electricity utilities coexisted, the French National Innovation System did not encourage market competition. Even though EDF has been a limited-liability corporation under private law and no longer state-owned since 2004, 84.5 per cent of its shares are still retained by the French government (EDF 2014). Accordingly, EDF still holds its historic title of a 'state within a state' (etat dans un etat).

Second, supporting EDF, Areva is the main nuclear engineering firm and second major actor in the nuclear industry. Areva is divided into Areva Nuclear Power (Areva NP) and Areva Nuclear Cycle (Areva NC). Areva NP constructs the nuclear reactors, whereas Areva NC is responsible for fuel cycle expertise, including reprocessing spent fuel and waste management. Areva NC has had experience in dealing with nuclear waste and spent fuel since the construction of the recycling facility in La Hague in 1966. The third actor at the core of the industry is the Commissariat à l'énergie atomique et aux énergies alternatives (CEA), which was institutionalised in 1945 to undertake nuclear research for national defence interests. Today, it still provides a dual military and civil research service.

Coordination between and within institutions was guaranteed by the traditional French technocracy. After the Second World War, the workforce within an engineering firm in France was almost always entirely 
composed of members of the 'grand corps of the state' (corps d'etat). ${ }^{4}$ This meant that, during the nuclear acceleration, not only the Minister for Industry but also the chief executive officers and senior executive staff in the nuclear industry at the time had all studied at the same prestigious university, Ecole des Mines. Due to the homogeneity of their education, a natural efficiency arose between these three institutions and their executive leaders. As government officials often had previously worked within or with these prestigious institutions, the efficiency was extended to the political sphere. The proximity these historic institutions have with one another and with the government means that political grandes programmes could easily reach consensus from both right- and left-wing Members of Parliament, without much public debate (Gerbault 2011). This efficiency was moreover facilitated by the vertical integration of the nuclear value chain within the single institutions. The grand result of this centralised and integrated configuration was an easy and undisputed nuclear acceleration. ${ }^{5}$

The last defining element responsible for the French nuclear industry's political strength is France's reliance on nuclear exports. First, France is the largest electricity exporter in the world and part of the European Union's (EU) interconnected electricity grid. In 2015, France generated 546 terawatt hours (TWh) compared to $476 \mathrm{TWh}$ consumed (RTE 2016). This tells us that the electricity capacity in France is on average much higher than it needs to be in order to sustain domestic consumption. For technical reasons, it is costly to shut down a nuclear power plant and restart it. Therefore, as electricity demand fluctuates, exports are essential to keep nuclear power plants operating at a roughly constant rate. France enjoys nuclear dominance thanks to the European interconnected grid, which gives the industry the opportunity to generate constantly at a surplus.

Also in 2015, France exported 91.3 TWh of electricity and imported 29.9 TWh (RTE 2016). The quantity that is being imported reflects the electricity price volatility and that nuclear is not always the cheapest option in the EU. On the one hand, Switzerland imports most of the French exported electricity, followed by Italy, Germany, Belgium, the UK, and Spain. On the other hand, France imports mainly from Germany, when renewable electricity is produced more cheaply than nuclear power,

4 The corps d'etat historically includes graduates from prestigious engineering schools (such as les Mines and Des Ponts) as well as the National Institute of Statistics and Economic Studies.

5 Other actors such as the Autorité de sûreté nucléaire (ASN) are discussed later. 
as well as from Switzerland and Spain. As heating-cooling systems are primarily electric in France, it is the most thermo-sensitive state in the western European region. Even with an average surplus of nuclear power, during winter cold spells France does not have enough dispatchable capacity and is forced to import electricity from neighbouring countries.

Second, France exports nuclear reactors. Areva NP constructs the nuclear reactors and has exported 102 light-water reactors (LWR) worldwide. Most recently, Areva is exporting a new reactor design, the European pressurised reactor (EPR). There are four examples of current EPR builds: one in Finland, two in China, and one in France. However, this new technology is proving problematic, symbolised by the controversy related to the Hinkley Point $\mathrm{C}$ investment for the construction of two EPRs in the UK. The details concerning the underlying issues about the EPR design and its export opportunity will be discussed later.

Third, France exports reactor safety expertise. ${ }^{6}$ Reactor safety standards have become a major export opportunity since the international accidents of Chernobyl and Fukushima. In fact, France has been very active in developing security norms at a European level since the aforementioned disasters made additional precautions necessary.

Fourth, as part of France's safety expertise, Areva NC has been able to export a fuel reprocessing plant, similar to the one in La Hague, in Rokkasho, Japan. More on the topic of radioactive waste management is discussed in the third section of this chapter.

Together, if all direct and indirect value streams of nuclear exports are considered, according to a study by PricewaterhouseCoopers Advisory (2011), close to $€ 6$ billion worth of exported nuclear electricity and other nuclear goods and services are gained annually, making nuclear power represent a potential $€ 45$ billion turnover and 2 per cent of French gross domestic product (GDP). Nuclear exports represent a significant revenue stream that France currently heavily relies on.

6 According to French Law No. 2006-686 on transparency and security in nuclear matters, nuclear security includes both nuclear safety (referring to the construction, functioning, and decommissioning of nuclear reactors) as well as radioprotection, prevention against malevolent acts, and civil security in the event of an accident. 
In the 1970s, France made decisions that locked the energy sector into a nuclear technology pathway for electricity generation. Its military origin enabled nuclear investment, the main industry actors are close to government, and the economy depends on nuclear exports. This explains how the industry historically became so exceptional. For the industry to actually be able to trump political plans to reduce the share of nuclear power, the configuration has to remain stable and exports successful. However, a critical technicality threatens these two elements: the end of the current nuclear fleet's lifetime. No matter the policy, the fleet will have to be replaced this decade. This gives additional room and strength to the French policy, which fits into a broader global energy transition, to step in and propose an alternative to replacing the fleet with new nuclear reactors. Pressure for a new global energy paradigm coincides with the necessity to have a new power fleet, and potentially to transition to a more renewable system if the nuclear industry cannot prove its new reactor design and how nuclear will fit into this new energy paradigm.

\section{A new energy paradigm}

Globally, environmental and climate concerns are creating the foundation for a new energy paradigm; the divorce from fossil fuel-based growth and the increase of renewable energy generation. France indeed has a lowcarbon economy based on nuclear power; however, as the reactor fleet in France has an average age of 31 years in 2016, it will soon reach the end of its official lifetime. ${ }^{7}$ France's political energy plans and the global transition align with the need for the current fleet to be replaced, creating a unique opportunity for a new energy system. Hollande's Energy Transition Law is a first indication of what the political overarching plans and objectives are for the new system.

This section discusses the role that the nuclear industry in France has had in the conversation about the new energy paradigm. First, I analyse the details of the Energy Transition Law for the nuclear industry and how it is being enforced in France. Next, there is a growing trend for increased renewable electricity capacity, which is accompanied by a downward market pressure on nuclear electricity, as renewable energy becomes competitive. This section concludes with an analysis of how nuclear

7 The initial lifetime of a nuclear reactor in France is 40 years. 
energy was perceived during the United Nations Framework Convention on Climate Change Conference of the Parties' (COP) negotiations in Paris (COP21) and whether it will be part of the new energy paradigm.

The Energy Transition Law stipulates a series of objectives for France to transition to a more sustainable economy. The motivations for this law originated with the Fukushima accident. During the presidential campaign of 2012, a debate around the future of energy began between Nicolas Sarkozy supporting nuclear power and Hollande supporting renewable energy. The final law text is based on the conclusions that were made during the 2012-13 national public energy debate on how to achieve a sustainable energy system. Although the law suffered a fierce political battle with more than 1,000 amendments, ${ }^{8}$ in 2015 it was finally presented as the most ambitious energy law to date by the former Minister for the Environment, Ségolène Royal. The 66 articles contain most notably:

- a reduction in the share of nuclear energy production in the electricity mix: down to 50 per cent by 2025;

- a cap on nuclear power capacity: at the current level of 63.2 gigawatt electric (GWe);

- an increase in the share of renewable energy in the electricity mix: up to 40 per cent of final electricity production by $2030^{\circ}$ (by increasing the share of renewable energy up to 32 per cent of final energy consumption by 2030);

- a reduction of final fossil fuel energy consumption: 30 per cent reduction compared to 2012 figures by 2030;

- a reduction of final energy consumption: 50 per cent reduction compared to 2012 figures by 2050; and

- a reduction of greenhouse gas emissions: 40 per cent reduction compared to 1990 figures by 2030 .

8 The main topics that were disputed within the text of the law and that formed the amendments related to the date and even inclusion or not of a date for the reduction down to 50 per cent of nuclear, the nuclear cap exact figure, figures around the reduction in final energy consumption, and more ambitious targets for sustainable and low-energy intensive housing (Energiewende Team 2015). 9 This would be up to 32 per cent of the total final energy share, which was at 18.7 per cent in 2014 (RTE 2016). 
The Energy Transition Law, although ambitious and concrete, does not give any indication as to how the objectives will be met. This is the role of the Multi-Annual Energy Programme, which aims to give a detailed plan of action for how to reduce the nuclear share. On 1 July 2016, Minister Royal published a 275-page document on the ministerial website. The Programme was reviewed by the Energy Transition Expert Committee, the Autorité de sûreté nucléaire (ASN), and public consultation was undertaken, before it was officially adopted on 27 October 2016. There is not yet any mention in this document of how many reactors will be shut down. Decisions on closures and lifetime extensions beyond 40 years are stated to commence in 2019. The only quantitative detail concerning nuclear electricity generation is that annual nuclear production will be reduced by 10 to 65 TWh by 2023, meaning a reduction of only 2.5 to 15.6 per cent of current production. For reference, a $10 \mathrm{TWh}$ reduction only just corresponds to the shutting down of the two oldest reactors in Fessenheim. ${ }^{10}$ On average, $65 \mathrm{TWh}$ corresponds to 10 reactors being shut down.

Both the lower and upper limits are very different from the Court of Audit's estimations. In their report, 17 to 20 reactors will need to be shut down before 2025 in order to conform with the Energy Transition Law. Of course, these numbers are subject to gross electricity consumption and production increases; however, it still seems that there is a gap between the law and the document pertaining to how it should be enforced. Practically, this gap means that the nuclear lobby has material influential inertia and played a role in determining the Multi-Annual Energy Programme. Not a single reactor has been shut down in France since the Energy Transition Law was passed. The oldest still-operational nuclear plant in Fessenheim is at the centre of the controversy.

The pressures on Fessenheim to shut down are threefold: its official licence expiry date is 2018 , it lies in a seismic risk zone at the border with Germany, thus receiving international pressure for closure, and the Energy Transition Law itself. Concerning the end of its lifetime, former President Hollande had made it a campaign promise to shut down the Fessenheim reactor before the end of his mandate (2017). He was, however, unable to meet this promise, the responsibility of which has now been passed on to Presdient Emmanuel Macron. The international concerns regarding the

10 In 2015, the two reactors at the Fessenheim site generated $13 \mathrm{TWh}$. 
Fessenheim reactors and their proximity to the border are also legitimate, as the reactors actually have been stopped by the emergency systems on multiple occasions in the past because of technical issues.

The third legal deadline is due to a combination of the cap on nuclear capacity stated in the Energy Transition Law and the new EPR being built in Flamanville 3. Although the build of the new 1,650 MW EPR, the first of its kind in France, has been significantly delayed and has encountered numerous problems, it is expected that it will be commissioned in 2018 . As a result of the cap in the law, the two reactors at Fessenheim will have to be shut down before the Flamanville 3 reactor can come online. Despite immense pressure internationally and by the French government, EDF has only recently accepted to commence the legal requirements that would lead to the anticipated closure of the two reactors on the basis of previous unsatisfactory compensation. EDF stated that it would refuse the plant closure unless it received $€ 2$ billion to $€ 3$ billion, which is nothing close to the $€ 80$ million to $€ 100$ million that was proposed by former Minister Royal in May 2016 (Le Monde 2016). On 24 January $2017, € 490$ million were proposed by the government and seem to be the adequate compromise for EDF. Even so, the Fessenheim reactors remain fully operational today.

Since the election of President Macron, there has been renewed confidence that the energy transition will indeed accelerate. The nomination of environmental activist Nicolas Hulot as Minister of Ecological and Solidarity Transition is a sign that the energy transition will move forward. An illustration of this was the loss in EDF share value by 6.57 per cent the day of his nomination (Stothard 2017). President Macron has underlined that the reduction of the share of nuclear electricity production to 50 per cent is a priority, that he stands by the closure of the Fessenheim plant, and that the renewable energy objectives described by the Energy Transition Law will be taken seriously (Macron 2017). He remains, however, unclear and doubtful about the 2025 objective. While he has presented himself as active in the fight against climate change, nuclear is still a controversial topic. After five years of promised nuclear reduction with no results during Hollande's mandate, Macron remains realistic and not idealistic in his approach to nuclear politics. Indeed, he has cautiously said that the future of the nuclear industry will depend on two factors: the results from the ASN real cost of nuclear electricity evaluation to be held in 2018, and the possibility to reform the governance structure at EDF considering the difficulty that policy has to drive nuclear decisions. 
Even with activist Minister Hulot, the prospects for nuclear power under President Macron will be determined by external factors as he has recognised what little political power he has over the industry.

The nuclear industry is currently on track to scale-down the level of ambition of French energy policy plans; however, there is also downward pressure on the industry at a market level. Global market trends are favouring alternative renewable energy over nuclear power. Since the Kyoto Protocol was signed in 1997, countries worldwide are slowly implementing new renewable energy capacity. Between 2000 and 2015, wind, solar, and nuclear grid connections represented net cumulated capacities of 417 GWe, 229 GWe, and $27 \mathrm{GWe}^{11}$ respectively (Schneider et al. 2016). In the EU, the shift from nuclear to renewables is even more noticeable as electricity generated from nuclear plants has decreased by 65 TWh a year since 1997, whereas wind and solar generation have both increased by $303 \mathrm{TWh}$ and $109 \mathrm{TWh}$ respectively. The consequence of this renewables trend is an increase in the competitiveness of renewable energy compared to nuclear-generated electricity.

In order to compare competitiveness of different energy generation resources, the levelised cost of energy (LCOE) indicator is used. ${ }^{12}$ In the Organisation for Economic Co-operation and Development (OECD) countries, wind's LCOE fell by 50 per cent between 2009 and 2014, reaching in 2015 a median LCOE of just over US\$60 per megawatt hour (MWh) (ranging from US\$33 to US\$135 per MWh) (IEA 2015). In 2015, nuclear power's median LCOE was just over US\$52 per MWh (ranging from US\$29 to US\$64 per MWh). The LCOE estimates represent a very large range, making it arguable that in certain contexts renewable power today is already cheaper than nuclear electricity.

Contrary to popular belief and certainly to many French politicians' views, reaching 100 per cent renewable electricity is not necessarily more expensive than nuclear power. The French Environment and Energy Management Agency (Agence de l'environnement et de la maitrise de l'énergie, ADEME) published a pilot study in 2015 concluding that France could solely depend on renewable electricity by 2050 , and estimated that this scenario would be at a comparable cost to a situation including

11 This figure includes long-term operation reactors.

12 The LCOE includes installation and operational costs, taxes, maintenance, and revenue requirements of the system over its lifetime. 
nuclear power. The study provides two major conclusions in favour of renewable energy. First, renewable electricity production potential ${ }^{13}$ is estimated at 1,268 TWh per year, which is three times the estimated 2050 demand for electricity in France. ${ }^{14}$ The renewable electricity mix proposed by ADEME is 63 per cent wind (offshore and onshore), 17 per cent solar (photovoltaics and thermal), 13 per cent hydro, and 7 per cent renewable thermal (biomass and geothermal). The second conclusion to be drawn from the study is that the price of 100 per cent renewable electricity is in the same order of magnitude as the current political proposition of 40 per cent renewable and 50 per cent nuclear. With either the 100 per cent or 40 per cent renewables scenario, the cost of electricity has been estimated to be around $€ 120$ per MWh. In 2016, electricity costs were estimated at $€ 90$ per MWh. Ultimately, the price of electricity for end consumers would increase proportionally to the cost by 30 per cent compared to today's price, regardless of whether the government decides to transition to a 100 per cent renewable electricity mix or remain at 40 per cent for 2050 (ADEME 2015). These underlying conclusions, however, are very controversial. In short, even in France, there is growing market pressure favouring renewable electricity.

As the global energy paradigm is being primarily dictated by environmental concerns, to determine what role nuclear will have in this new paradigm, this last segment focuses on past COP21 negotiations. Whereas French policy and market trends are favouring renewables to the detriment of nuclear power, the international sphere is more ambiguous about what role nuclear will have in the global energy system. Although not a renewable energy source, nuclear is still a low-carbon energy source in comparison with fossil fuel plants. In 2014, the Intergovernmental Panel on Climate Change published its fifth assessment report and concluded that nuclear power has the second lowest life-cycle emissions analysis after wind generation sources (Schlömer et al. 2014: 1335). As nuclear power's carbon footprint is low, a controversy exists around its role in the climate change negotiations. Since COP21, held in Paris over a two-week period in December 2015, all 195 states have signed a binding agreement aiming to not exceed 2 degrees Celsius of global warming and, if possible, only 1.5 degrees Celsius by the end of the century. Furthermore, states plan to

13 Including solar, wind, biomass, geothermal, hydro, and marine.

14 This estimate takes into account technology-related energy efficiencies. 
review their Intended Nationally Determined Contributions pertaining to greenhouse gas mitigation and adaptation strategies every five years, the aim being that each new contribution will be more ambitious than the last.

As COP21 took place in the heart of France, it was expected that nuclear energy would be debated in the context of climate change, especially as EDF was one of its major sponsors. Surprisingly, it seemed nuclear was the elephant in the room. Although organisations with strong public opinions were present and had representative booths and side-events, direct attention was hardly put on the subject of the future for nuclear energy. Prior to the event, EDF had been tweeting so evidently in favour of nuclear that it was being accused of greenwashing. However, during the event itself, no discussions on this topic were initiated. The IAEA refused to explicitly advocate for nuclear power.

On the other side of the spectrum, Greenpeace, a strong environmentalist and anti-nuclear association, did not address the nuclear issue at all. The OECD organised the only official event referring to nuclear energy: 'Why the climate needs nuclear energy'. The latter was a small side-event that took place one day before the final text was agreed upon; enough to say it did not have an impact on the agreement. Nuclear power, although represented, remained passive. Even though no decision was made to explicitly include nuclear in the new energy paradigm, no decision was made to exclude it either. Concerning nuclear energy in the context of climate change, ambiguity is all that can be taken away from COP21. For now, climate change negotiations are shaping the new energy paradigm to be low-carbon but not necessarily only renewable.

It is understandable that the literature on the French energy projections does not come to a consensus; the position of the present French nuclear industry seems to contradict both long-term policy goals and market trends. Confirming this ambiguity, during historical events, such as COP21, where the decisions are being made about how future energy will be produced, there is no common global nuclear outlook. Environmental concerns are strengthening the renewables sector but not directly modifying nuclear power production. In fact, the only historical events that have ever led to dramatic changes in global nuclear production have been nuclear accidents. It was, in fact, the Fukushima accident that led to the political compromise between the Ecologist Party, which supports a complete nuclear phase-out, and former President Hollande, to include the nuclear reduction share in the Energy Transition Law. 


\section{Nuclear safety}

Both the Chernobyl and Fukushima accidents sent global messages on nuclear safety risks and were consequently followed by nuclear reactor closures. France has, however, historically been somewhat disconnected to this risky reality, as the industry has tried to dissimulate the danger of nuclear. This next section discusses how the French nuclear industry has resisted and is resisting the nuclear decline trend in response to safety risks. First, the French nuclear industry built a strong communication strategy to keep the reactors safe from public opinion concerns. This strategy was historically successful, especially after the Chernobyl accident. Second, however, after Fukushima, despite the industry's investments in nuclear safety reinforcements to maintain trust with the domestic population, French nuclear became unpopular. The last part of this section focuses specifically on waste and how the French industry is dealing with this particular aspect of nuclear safety.

The French nuclear industry has always paid great attention to nuclear risks and the importance of nuclear safety. Realising that the sheer concept of nuclear risk could be detrimental to the industry, it felt forced to dissimulate the danger of nuclear accidents. Perhaps the biggest nuclear propaganda in French history was the media release related to the Chernobyl accident: 'the Chernobyl radioactive cloud stopped at France's borders' (Morice 2011). Simplistically, the reason that was given to explain how this could be possible was that the wind was headed north and not west.

The nuclear industry focused on the positive side of nuclear energy, by referencing the independence from Russian gas and the modernity of nuclear technology. 'In France we may not have oil, but we have brains' was the national slogan used by Valéry Giscard d'Estaing during the 1974 political campaign. The nuclear industry's great efforts to fight nuclear scepticism related to nuclear accidents paid off, as the common belief that French nuclear technology is safe and that no accident has occurred is widespread and is even expressed in public declarations. In 2012, former French President Sarkozy explained: 'For as long as nuclear power has been generated in France, we have never experienced a major accident' (Vie Publique 2012). Pierre Tanguy, the Inspector General for 
EDF security, also asserted that there has never been a nuclear accident in France. There have, however, been numerous nuclear incidents, as is easy to believe considering the number of reactors.

Moreover, two nuclear accidents have also occurred but were not fully communicated through the media, giving the impression that the French reactors are of exceptional quality. One accident in particular, at the SaintLaurent-des-Eaux nuclear plant in 1980, was classified a level 4 accident on the International Nuclear and Radiological Event Scale (INES; see IAEA and OECD/NEA 2013). ${ }^{15}$ To gain perspective, both the Fukushima and the Chernobyl accidents were ranked at the maximal level of 7 . The SaintLaurent-des-Eaux nuclear accident resulted in a partial fuel meltdown and an automatic shutdown of the reactor. A level 4 nuclear accident indicates that there is 'limited off-site risk' (detailed definitions are provided in IAEA and OECD/NEA 2013) and minor radioactive release or 'public exposure of the order of prescribed limits'. However, it was publicised in 2015 that there was also radioactive release into the river Loire due to the 1980 Saint-Laurent-des-Eaux accident.

The investigators who provided the evidence for the documentary Nucléaire, la politique du mensonge, revealed that there had been an ongoing release of plutonium into the river for a duration of five years since the accident occurred (Canal+ 2015). By comparison, the Three Mile Island accident in Dauphin County, Pennsylvania, in 1979, which included a nuclear meltdown and release of radioactive material into the Susquehana River, was ranked at level $5 .{ }^{16} \mathrm{It}$ is surprising how the accident of Saint-Laurent-des-Eaux did not have a similar media effect on the French public's perception of nuclear safety as the Three Mile Island accident did in the US. Vague communication has been a useful tool to reassure the French public after such accidents. Neither the SaintLaurent-des-Eaux, the Three Mile Island, nor the Chernobyl accidents affected nuclear energy growth in France owing to the industry's danger dissimulation efforts.

In contrast to the accidents from the twentieth century, the accident in 2011 in Fukushima occurred in a new globalised world. In other words, since the nuclear industry is a global market, the accident had more wide-

15 The lower levels refer to incidents, whereas the higher levels refer to more significant accidents.

16 Level 5: 'Limited release: Likely to require partial implementation of planned counter-measures' (see IAEA and OECD/NEA 2013). 
ranging impacts, such as the announced nuclear phase-outs. Still, France did not choose at the time to change energy policy. Sarkozy reaffirmed on 24 March, just after the accident, that the nuclear energy policy was not to be questioned (INA 2011). However, the French industry's global position in the nuclear market was undeniably affected.

It is worth studying how France reacted to the Fukushima accident as a means to test the strength of the industry against trends for nuclear decline. At a European level, France had to prove that it still had the most reliable fleet by exporting safety expertise. France boosted public trust by being extremely active at a European level and providing maintenance and security measures to reinforce security thresholds, which were consequently integrated into the European Nuclear Safety Framework. ${ }^{17}$ For example, nuclear plants in the EU since the Fukushima accident are obliged to withstand an incoming aeroplane crash.

At a national level, the French reaction to the Fukushima accident was to reaffirm the safety of the French reactors. To do so, the independent nuclear safety authority ASN was given permission for the first time to carry out audits of all 58 reactors. ${ }^{18}$ The conclusions of these audits noted that even though no immediate shutdowns would take place, safety reinforcements had to be made as soon as possible. The suggestions made by the ASN included increasing back-up cooling capacity, crisis control centres, and the obligation that each plant have a 'rapid reaction force', meaning staff that are trained specifically to control nuclear emergencies. At the time, these safety reinforcements were estimated to cost $€ 13$ billion (Crumley 2012).

Despite the industry's efforts to regain trust through safety investments, these were not enough to avoid a serious dip in public opinion polls regarding the popularity of nuclear energy.

In June 2011, the Ipsos Mori poll was conducted and collected data suggesting that 67 per cent of the French population either somewhat or strongly opposed nuclear power (Ipsos 2011). Another poll showed that

17 As the initiator of the Western European Nuclear Regulators Association, the French nuclear industry was very active in informing how to undertake the 'stress tests', drawing from its own experiences and expertise. The 'stress test' refers to the risk and safety assessments to be carried out on all EU nuclear plants after the Fukushima accident (Ministère du Developpement Durable 2012; Dehousse with Verhoeven 2014).

18 French Law No. 2006-686 on transparency and security in nuclear matters mandated the founding of the ASN, an independent administrative authority. 
57 per cent of French respondents were in favour of phasing out nuclear power (Buffery 2011). At this stage, there was evident conflict between public opinion of nuclear and the nuclear industry, the latter dismissing the safety concerns. Despite continued nuclear power generation, public opinion in 2011 showed signs of the precarious situation that the French nuclear industry is now in. The risk of nuclear accidents, although not strong enough to shut down any reactors in France, is undermining the 'safe' image that the industry had worked so hard on and thus is weakening the industry's political influence.

A case study for controversy between public opinion and the French industry related to nuclear safety is nuclear waste management. The difference with waste, as opposed to nuclear accidents, is that closing down reactors will not eliminate the problem. Half a century's worth of waste has already been produced and is waiting to be disposed of properly. Although for many countries the issue of nuclear radioactive waste alone has been enough to discourage them from engaging in nuclear power activities, France has once again taken a strategic route to dissimulating the danger involved. The promise was made that nuclear energy produces little waste, in fact no more than the equivalent volume of 'an Olympic swimming pool', according to Anne Lauvergeon during her time as president at Areva between 2001 and 2011.

In fact, the total volume of radioactive waste in France at the end of 2013 was estimated at 1,460,000 $\mathrm{m}^{3}$ (ANDRA 2013), 60 per cent of which was derived from nuclear totalling $880,000 \mathrm{~m}^{3}$. Although this is much less than any fossil fuel power industry has created, it is certainly more than an Olympic swimming pool's volume (close to $3,000 \mathrm{~m}^{3}$ ). Not only political euphemisms originating from the strong nuclear lobbies are used, but also direct influence on what is officially considered as nuclear waste shows the stronghold that the industry has on policy. The articles related to radioactive waste management in French Law No. 2006-686, for example, state that if a material can be potentially reused it is not considered as waste. ${ }^{19}$ As materials containing uranium and plutonium can both be potentially reprocessed, any radioactive component containing these elements has been excluded from the official quantity of waste.

19 'A radioactive material shall include any radioactive substance that is intended for future use, after treatment, if need be. Radioactive waste shall include any radioactive substance for which no further use is prescribed or considered'. 
France's partial solution to the waste issue so far has been its fuel cycle expertise, led by Areva NC. The site in La Hague was built by Areva NC to 'recycle' nuclear waste by reprocessing spent uranium fuel, and separating the plutonium. The separated plutonium can then be used as mixed-oxide fuel for France's LWRs. There is a difference, however, between what has been recycled and what is recyclable. The La Hague site stores its recyclable material before reprocessing it and, if not used, the recyclable or 'recoverable material' ${ }^{20}$ ends up in the waste category. Not all the 'recoverable material' is French. For example, Germany, Belgium, the Netherlands, Switzerland, and Japan have used the facilities in La Hague to process their spent fuel and to avoid conflict with their publics over waste storage; these orders, however, are declining (Schneider and Marignac 2008; International Panel on Fissile Materials 2015).

Nuclear fuel reprocessing and enriching poses several issues. First, plutonium extraction capacities raise the controversy of nuclear proliferation. In fact, to foster transparency, as Mark Diesendorf suggests, 'all civil uranium enrichment and reprocessing facilities [should] be placed under international control' (Diesendorf 2014). Second, reprocessing fuel is costly and generates large volumes of low-level waste. ${ }^{21}$ The La Hague facility can only process up to 1,700 tonnes of heavy metal (tHM) of spent fuel a year. Knowing that LWRs use on average 21 tonnes of fuel and discharge 20 tonnes of spent fuel annually, France produces roughly 1,000 tonnes of spent fuel each year (Feiveson et al. 2011). Since the beginning of reprocessing, about 30,000 tHM of fuel have been reprocessed. Currently, roughly 1,200 tHM of fuel is being processed each year. ${ }^{22}$ By the end of 2007, 13,500 tHM of nuclear spent fuel were still awaiting reprocessing in cooling ponds and dry cask storage areas at La Hague as well as on nuclear plant sites (Feiveson et al. 2011).

It has been known since its creation that the facility at La Hague produced radioactive waste that had to be managed in the long-term and the evident accumulation of waste finally encouraged the development of a geological underground radioactive waste disposal solution. Geological disposal of nuclear waste has been undergoing research for over 20 years in France, and has been actively controversial since the first mention of this possible

20 Recoverable material includes natural uranium, enriched uranium, plutonium, thorium, and spent fuel.

21 Low radioactivity level and long half-life.

22 Of which only 8.5 tHM of plutonium can be reused, the rest would end up in storage. 
solution in the 2006 law and development of the Cigéo (Centre industriel de stockage géologique) project. This project was developed to design a solution for high-level and long half-life radioactive long-term waste management. If the project is accepted, the underground geological storage site would be situated at $500 \mathrm{~m}$ depth in the commune of la Bure in the department of Meuse in eastern France, and would be able to store up to $80,000 \mathrm{~m}^{3}$ of waste for millennia. The only other approved site of its kind is in Olkiluto, Finland. According to French law, it must be assured that the solution is also reversible in the event that a better waste management solution is discovered (Cigéo.com 2013).

The Cigéo project is currently the only viable solution for managing this type of waste; it is, however, extremely unpopular as residents near Meuse consider environmental and health impacts of living near a radioactive garbage dump (Le Monde 2015). Costs also contribute to the controversy; the Court of Audit estimates that the cost of the Cigéo project could reach $€ 43.6$ billion (taking into account increases in waste quantities) (Collet 2016). If the industry cannot manage waste correctly, its political influence will be further weakened.

After the Chernobyl accident, media and communication dissimulation was enough to keep public opinion stable. However, since the Fukushima accident, public opinion has been clearly disturbed. Still, the industry has been influential enough to keep its number one placeholder in the electricity market. The waste issue is more complex as it is an existing and growing long-term safety concern, exposing added costs to an already expensive safety investment. Instead of responding to nuclear risks by shutting down reactors, France has invested in nuclear safety, which will be an investment with never-ending, escalating costs.

\section{The economics of nuclear energy in France}

This last section focuses on the financial risks that are threatening the viability of France's nuclear industry. The extent to which the industry will be able to influence or resist government plans to reduce the share of nuclear power will ultimately be determined by whether it can financially continue as a commercial business. Each previous section has hinted at the economic concerns related to renewing the fleet, competitive renewable energy, and safety standards. 
This section analyses the industry's financial situation. First, the current state of financial affairs in France shows signs of a weakened industry. Second, based on the factors that got the industry into this financial position, an analysis of the 'nuclear bill' sheds light on the industry's prospects for recovery. Third, the Hinkley Point C reactor controversy sums up the uncertainty on the economics of future nuclear builds.

In recent years, the world has witnessed a French nuclear industry financial crisis. Since 2011, Areva has been facing debt and bankruptcy challenges. In November 2014, Areva was rated by Standards and Poor's and downgraded to $\mathrm{BB}+$ ('junk'). The monopolistic reactor engineering company accumulated $€ 6.3$ billion worth of debt in 2015 (Areva 2016), by which time its rating was once again downgraded to BB-. ${ }^{23}$ Areva faces not only the problem of capital debt, but also of a skills gap. The last nuclear plant to be built in France was in 1993. The 1993 workforce lived through the 1970s nuclear expansion and had sound knowledge and experience of the nuclear field. However, as the construction of the Flamanville EPR began in 2007, 14 years since the last build, the active French nuclear workforce is either old and retiring or young and inexperienced. The skill gap and increasing operational costs are contributing to Areva's debt. Therefore, encouraged by the French government, a rescue plan for Areva's financial issues was decided upon.

EDF bought the majority of Areva NP for $€ 2.7$ billion in 2015. EDF now bears the entirety of the nuclear investment risk for France, and so its own fate is also heading towards an increasing debt, which by the end of 2015 was at $€ 37.4$ billion (EDF 2016). On 21 December 2015, EDF's risk profile got the company eliminated from the Commissariat aux Comptes 40 (CAC40). ${ }^{24}$ Since entering the CAC40 10 years ago with shares worth $€ 32$, EDF's share value has decreased by 70 per cent, reaching $€ 9.75$ in January 2017 (Boursier.com 2017).

In addition, EDF faced deregulated electricity prices for the first time in 2016. Even though France passed legislation in 2007 to accommodate the European directive 92/96 for a liberalised European Electricity Market, in France the electricity market had hardly changed. In order to fully liberalise the market to competition, the Nouvelle Organisation

23 Areva's turnover was $€ 4.2$ billion in 2015 (Areva 2016).

24 The CAC40 is a benchmark in the French stock exchange market index. The 40 highest performing largest equities are part of the CAC40 and typically include France's most successful businesses. 
du Marché d'Electricité Law of 2010 states that in 2016 the prices shall no longer be regulated for residential and professional consumers that have high electricity power requirements (at least 36 kilo-volt-amperes). ${ }^{25}$ Instead of the state determining the electricity price based on EDF's financial needs, electricity prices shall be determined each year by the Commission de régulation de l'énergie.

EDF is losing clients and electricity price stability benefits. Especially as operational costs for EDF are increasing, a decrease in the electricity wholesale market price because of competition is affecting EDF's revenue stream significantly. Slowly but surely a wedge between political support and the nuclear industry, practically represented by EDF, is undermining the industry's political authority. ${ }^{26}$

For EDF to have any hope of regaining its monopolistic position in the electricity market, it will have to return to a financially stable position. To understand whether this development could eventuate, an analysis of the future economic risks associated with EDF's current financial position are discussed in this section. The 'nuclear bill' that symbolises the magnitude of these economic risks will consider the major costs that the industry will have to pay to continue doing business. For this analysis, we will only consider certain major costs, including fleet reparations (in line with safety measures), decommissioning, and, most importantly, the costs associated with the new EPR design.

\section{Fleet reparations}

As the fleet is reaching its life's end and it seems that in the short-term France is still on its way to continue nuclear production and not a phaseout, reactor's lives will have to be prolonged. Prolonging the lifetime includes reparations and maintenance in accordance with new safety standards for the whole fleet. EDF has estimated that it would cost $€ 55$ billion to prolong the lifetime of the entire current fleet by 10 years. If this is not already an enormous investment, the Court of Audit has estimated that this figure could well turn out to be double that.

25 The deregulation of electricity prices for residential customers is due to start in 2019.

26 Other significant costs, such as those pertaining to safety investments as mentioned earlier, will also contribute greatly to the 'nuclear bill'. 


\section{Decommissioning}

EDF's debt could also increase due to decommissioning costs. France has little experience with even the beginning phases of decommissioning. Brennilis is the first French plant to have begun a decommissioning process. Since 1985, when it was first shut down, decommissioning of this plant has cost almost $€ 500$ million over a duration of 35 years. As the definition of a 'decommissioned power plant' has not been clearly articulated, EDF refers to a decommissioned site as having a status equivalent to 'unrestricted public reuse'. EDF has estimated that it could cost $€ 30$ billion ( $€ 500$ million per plant) to decommission the entire current fleet. However, according to the Court of Audit, this is clearly an underestimate. The main reason given by the Court of Audit is that cost estimates of decommissioning in other countries have been much higher. For example, in the UK, decommissioning of 35 reactors is likely to cost $€ 103$ billion. ${ }^{27}$

\section{A new EPR design}

The final major cost for the industry relates to the renewal of the nuclear fleet in order to sustain current nuclear capacity after plants are decommissioned. Areva and EDF's solution to this issue is the EPR. Examples of the building time frames and costs will enable this analysis to determine how future investments in this technology might turn out. Areva boasts that the EPR is 'among the most powerful reactors in the world'. It is considered a Generation III model because of its high performance (1,650 MW capacity as opposed to 1,450 MW for Generation II reactors) and safety structures. Areva promised that electricity production costs would be 10 per cent less than with the Generation II plants. Other advantages of this new technology include a lifetime increase of 20 years, easier maintenance, and shorter construction time (only 57 months) (Areva 2017). The last promise made by the industry was that the EPR design would also be cheaper to construct compared to previous reactor designs.

Worldwide, there are four EPR plants being constructed by Areva. The unit 3 reactor in Flamanville has been under construction since 2007 and was originally set to come online in 2012 . The original cost for construction

27 Each UK reactor has an average capacity of $900 \mathrm{MW}$ (Goldberg 2010). 
was estimated by EDF at $€ 3.3$ billion. Since 2007, construction delays and cost overruns have occurred after security assessments made by the ASN. In May 2008, construction was suspended due to 'anomalies' of the iron framework. Repairs resulted in an increase in costs by 20 per cent and an extra year of construction. After the Fukushima accident in 2011, along with new safety measures, new tests had to be completed, materials reinforced, and construction times increased, pushing back the operational date by another two years. After material shipping delays and a recent anomaly on the reactor vessel discovered in April 2015 by the ASN (2016), the plant should be operational by 2018 at a cost of $€ 10.5$ billion (see Figure 2.1).

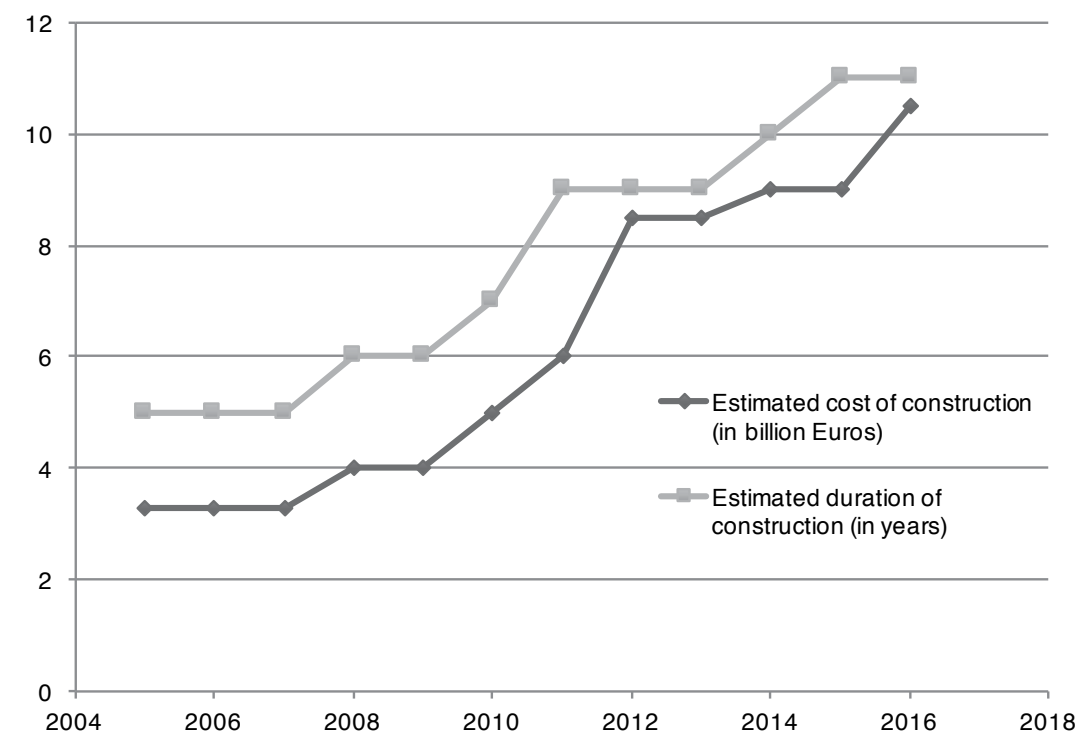

Figure 2.1 Evolution of costs and duration of construction estimates for the EPR in Flamanville

Source: Based on Soleymieux (2015) and reprinted with permission of the author.

In 2010, former EDF president François Roussely highlighted the reasons behind the Flamanville EPR failures by compiling a series of much contested radical recommendations to improve the outlook of the industry (Roussely 2010). Roussely provided insight into Frenchspecific challenges. During the early stages of the EPR construction, EDF and Areva were distanced for business-related reasons. A lack of strategic coordination between both bodies impaired communication and thus commercial inefficiencies arose. Roussely also pointed to the 
complexity of the design of the EPR itself to be one of the reasons why it is encountering so many construction problems. According to his analysis, the fact that the French nuclear industry has not been able to attract any private investment and has always relied on state backing is another sign pointing to why the EPR projects are so economically challenging - they are simply not economically competitive. Although EDF and Areva are closer than they have ever been before, the issues that the EPR is facing clearly expose the fragility of this design.

So far, it seems that to invest in such costly and technically risky technology may not be feasible. Only if the new EPR model can be standardised would it be able to experience a decreasing learning curve thanks to economies of scale. There are EPRs under construction in Flamanville, Olkiluoto, and Taishan; as the same technology is being used in all cases, one could expect that the learning curve should already be decreasing or at least that the construction duration should decrease as lessons are being learnt. In reality, this is not the case. Instead, each project has taken on the characteristics of a 'first of a kind' technology. Mauro Mancini (2015) explains that intrinsic nuclear build characteristics disable a decreasing learning curve. These include location-specific characteristics, such as experience of the available workforce and the local political situation. If we compare, for example, the Flamanville nuclear power plant with the other EPR projects, high cost overruns and delay problems have occurred even though the same technology has been used.

The EPR at the Olkiluoto site had an original delivery price of $€ 3$ billion and was supposed to be commercially operational by 2005. In 2012, Areva re-evaluated this cost at $€ 8.5$ billion and, in January 2016, the operational date was pushed back to 2018. The two Taishan reactors began construction in 2009 and 2010 and were planned to go online in 2013. The current predicted date for commercial operation is the fourth trimester of 2018 (EDF 2017). At a potential cost of $€ 8$ billion for both reactors and a four-year delay, these nuclear EPR constructions are a relative success story compared to the French and Finnish experiences.

There are, however, lingering doubts about the quality of certain components and the security of the entire plant design (Radio Free Asia 2016). These concerns have been evident since April 2016, when the ASN discovered excessive carbon in the EPR design's main vessel (ASN 2016), which could lead to serious safety issues if cracks were to develop in consequence to the sub-optimal mechanical properties of the 
reactors. These concerns would eventually increase costs and push back the operation dates again. The EPR has been unsuccessful in establishing a reliable new design and there is no clear path for new construction in France. The EPR experience therefore puts serious doubt on the potential revenue streams that the industry would be able to derive from both EPRgenerated electricity as well as EPR exports.

To highlight the industry's precarious financial situation, this very last section exposes the Hinkley Point $\mathrm{C}$ controversy. On the one hand, EDF has its reputation and possible growth at stake; on the other hand, this investment is so costly that the risks involved in going through with the project could lead to the downfall of the entire industry. Owned primarily by EDF and one-third by a Chinese contractor (China General Nuclear Power Corporation, CGNPC), the Hinkley Point $C$ project includes two EPRs being built at Somerset. The two reactors are assumed to eventually cover 7 per cent of the UK's electricity demand. The cost for the two reactors in Somerset was originally estimated at $£ 16$ billion in 2013. This estimate was increased by $£ 2$ billion in October 2015 and the completion date was shifted from 2023 to 2025.

The cost-related part of the controversy contributed the most to delaying the final investment decision. As Simon Taylor (2016: 3) points out, Hinkley Point $\mathrm{C}$ will be 'the most expensive power station in history'. Indeed, it is setting out to be the most expensive object on earth. In March 2016, the chief finance officer of EDF, Thomas Piquemal, resigned because of the financial risks involved with accepting the Hinkley Point C investment. The Workers Council also protested against this investment actively, even though the state supports the project (Schneider and Froggatt 2015). EDF argues that although the cost of the plant was estimated in January 2016 at $€ 25$ billion, the payoff for France will be rich, as the UK agreed to pay $£ 92.5$ per MWh for 35 years for the generated nuclear electricity. When the first contract was drafted in 2012, this price was double the electricity wholesale price; it is now three times the current electricity wholesale rate (Economist 2016), making Hinkley Point $\mathrm{C}$ a very attractive deal for $\mathrm{EDF}$ - if it can deliver. Piquemal did not think it could and resigned.

In addition, a few hours before the investment decision was made on 28 July 2016, Gérard Mongin, one of the 18 board members who had the responsibility of making the decision at EDF, resigned as well (Cosnard 2016). Two spectacular resignations have occurred to symbolise 
the risk. Yet, after Mongin left, the decision was finally made to go ahead with Hinkley Point C (Bernard and Cosnard 2016). Bernard Lévy, chief executive officer at EDF, expected that all obstacles had now been overcome and that the project could begin. Another surprise event, however, took place the following day when Greg Clark announced ' $[t]$ he government will now consider carefully all the component parts of this project and make its decision in the early autumn' (Financial Times 2016). On 15 September 2016, British Prime Minister Theresa May officially gave the 'green light' to the project. The Hinkley Point $\mathrm{C}$ reactor clearly shows that the economics of the potential plant do not add up. It is in the hands of governments to support the investment if there is any chance of EDF not collapsing. It is fair to say that to regain financial stability, the industry needs support from the state, both financial and political.

It is obvious that the main actors of the nuclear industry, Areva and EDF, are in a financial crisis. The reasons behind their financial situation are linked to previous costs and the risk of future costs escalating beyond already high estimates. Even though the government is against supporting EDF financially for internal costs related to continuing nuclear power generation, as this would be against national policy, it is in favour of a strong nuclear export capacity. Economics will ultimately determine the future of national nuclear growth. Regarding external growth, however, this will depend on the success of the EPR design. As the design is in some cases economically unfeasible, its success will be determined by politics.

\section{Conclusion}

It is fair to say that the nuclear industry in France will not remain as it is today. The exceptional status it once had may give way to a more compromised position. Although the nuclear industry represents enormous political strength and stability, the consequences of the Energy Transition Law and efforts to reduce safety risks are rendering nuclear uncompetitive. The elevated costs of keeping the industry afloat reflect the high level of risk that the entire nuclear industry is facing. Nuclear investments without government support are nearly impossible. In the end, the question is whether the economics of nuclear will trump the political power of the nuclear establishment. Within France's borders, the electricity market is becoming so open to competition that the nuclear industry will cease to dominate electricity generation, as renewables will undercut nuclear prices. This will, however, not be a hastened decline, for 
as long as the current fleet's reactors are still generating, their electricity will be sold. The industry can only influence the speed of the transition, while it is heading towards an economically hostile environment. Outside of French borders the prospects are also quite bleak, despite the state backing the nuclear export industry. France could continue to extract revenue from safety expertise, waste management processes, and perhaps from the new EPR design. For this last case, it will not be a matter of economics but a matter of political support and, more importantly, proof to foreign governments that the EPR design can indeed deliver, which will determine sales of this Generation III reactor.

Could the French nuclear establishment have enough power to resist current political objectives to reduce the share of nuclear and favour renewables? In the long term, no. In the short term, however, the industry will influence the magnitude and speed of the decline in the context of the new low-carbon energy paradigm. The nuclear industry is going through its own transition, focusing more on exports such as the EPR to secure revenue, as the economics set pessimistic prospects for nuclear to continue dominating the national energy system. The new French energy paradigm does not contradict the growth and strength of the nuclear industry; both will transition together to accommodate a more sustainable system favouring renewables and nuclear exports.

\section{References}

ADEME (Agence de l'environnement et de la maitrise de l'énergie), 2015. Un mix electrique $100 \%$ renouvelable? Analyses et optimisations. October. Angers: ADEME. www.ademe.fr/sites/default/files/assets/ documents/rapport_final.pdf (accessed 1 February 2017).

ANDRA (Agence nationale pour la gestion des déchets radioactifs), 2013. Les volumes de déchets. www.andra.fr/pages/fr/menu1/les-dechetsradioactifs/les-volumes-de-dechets-11.html (accessed 1 February 2017).

Areva, 2016. 2015 annual results. Press release, 26 February. www.areva.com/EN/news-10717/2015-annual-results.html (accessed 1 February 2017).

Areva, 2017. EPR ${ }^{\mathrm{TM}}$ reactor: The very high power reactor (1,650 MWe). www.areva.com/EN/global-offer-419/epr-reactor-one-of-the-mostpowerful-in-the-world.html (accessed 9 February 2017). 
ASN (Autorité de sûreté nucléaire), 2016. Note d'information: L'ASN met à la disposition du public plusieurs courriers envoyés à AREVA depuis 2006 sur la fabrication de la cuve de l'EPR de Flamanville. 20 April. www.asn.fr/Controler/Actualites-du-controle/Controle-du-reacteurEPR-en-construction/Anomalies-de-la-cuve-de-l-EPR/Courriersrelatifs-a-la-fabrication-de-la-cuve-de-l-EPR-de-Flamanville (accessed 1 February 2017).

Bernard, Philippe, and Denis Cosnard, 2016. EDF décide de lancer Hinkley Point, Londres tergiverse. Le Monde, 28 July.

Boursier.com, 2017. EDF. www.boursier.com/actions/cours/edf-FR00 10242511,FR.html (accessed 9 February 2017).

Brottes, François, and Denis Baupin, 2014. Rapport fait au nom de la commission d'enquête relative aux coûts passés, présents et futurs de la filière nucléaire, à la durée d'exploitation des réacteurs et à divers aspects économiques et financiers de la production et de la commercialisation de l'électricité nucléaire, dans le périmètre du mix électrique français et européen, ainsi qu'aux conséquences de la fermeture et du démantèlement de réacteurs nucléaires, notamment de la centrale de Fessenheim - Tome I. Assemblée nationale, July.

Buffery, Vicky, 2011. Majority of French want to drop nuclear energypoll. Reuters, 13 April.

Canal+, 2015. Nucléaire, la politique du mensonge. Film documentary. May.

Chantebout, Bernard, 1986. La dissuasion nucléaire et le pouvoir presidential. Pouvoirs 38, L'armée 21-32.

Cigéo.com, 2013. Operations at Cigéo. 30 August. www.cigéo.com/lefonctionnement-du-centre (accessed 1 February 2017).

Collet, Philippe, 2016. Cigeo: Segolene Royal fixe l'objectif de cout a 25 milliards d'euros pour le stockage des dechets radioactifs. Actuenvironnement.com, 18 January. www.actu-environnement.com/ ae/news/dechets-radioactifs-cout-objectif-cigeo-arrete-26065.php4 (accessed 1 February 2017).

Cosnard, Denis, 2016. EDF: hostile au projet Hinkley Point, un administrateur du groupe claque la porte. Le Monde, 28 July. 
Crumley, Bruce, 2012. The Fukushima effect: France starts to turn against its much vaunted nuclear industry. Time, 4 January.

Dehousse, Franklin, with Didier Verhoeven, 2014. The nuclear safety framework in the European Union after Fukushima. Egmont Paper 73. Brussels: Academia Press for Egmont, Royal Institute for International Relations.

Diesendorf, Mark, 2014. Sustainable Energy Solutions for Climate Change. Sydney: UNSW Press.

Economist, 2016. What's the (Hinkley) point? 25 February.

EDF (Électricité de France), 2014. Investisseurs et analystes. www.edf. $\mathrm{fr} /$ groupe-edf/espaces-dedies/finance/investisseurs-et-analystes/lessentiel (accessed 1 February 2017).

EDF (Électricité de France), 2016. Net financial debt and cash flow: Change in net financial debt. 30 June. www.edf.fr/en/the-edf-group/ dedicated-sections/finance/investors-analysts/credits/net-financialdebt-and-cash-flow (accessed 1 February 2017).

EDF (Électricité de France), 2017. La centrale nucléaire de Flamanville: Une production d'électricité au cœur de la Normandie. Dossier de Presse, January. www.edf.fr/sites/default/files/contrib/groupe-edf/producteurindustriel/carte-des-implantations/centrale-flamanville $\% 203 \% 20$ -\%20epr/presentation/2017dpfla3.pdf (accessed 7 September 2017).

Energiewende Team, 2015. So far, so good? The French energy transition law in the starting blocks. Energy Transition, 29 July. energytransition. org/2015/07/french-energy-transition-law/ (accessed 1 February 2017).

Feiveson, Harold, Zia Mian, M. V. Ramana, and Frank von Hippel, eds, 2011. Managing Spent Fuel from Nuclear Power Reactors: Experience and Lessons from Around the World. Princeton, NJ: International Panel on Fissile Materials, Program on Science and Global Security, Princeton University.

Financial Times, 2016. UK under fire over fresh delay to Hinkley Point nuclear plant. 16 July.

Gerbault, Alain, 2011. Les atomes crochus des politiques avec le nucléaire. Slate, 14 March. www.slate.fr/story/35467/lobby-nucleaire (accessed 1 February 2017). 
Goldberg, 2010. Combien coûtera le démantèlement du nucléaire? L'expansion, 7 January.

IAEA (International Atomic Energy Agency), 2014/2015. Energy, electricity and nuclear power estimates for the period up to 2050 . Vienna: IAEA.

IAEA (International Atomic Energy Agency) and OECD/NEA (Nuclear Energy Agency), 2013. INES: The International Nuclear and Radiological Event Scale User's Manual: 2008 Edition. Vienna: IAEA. www.iaea.org/sites/default/files/ines.pdf (accessed 1 February 2017).

IEA (International Energy Agency), 2015. Projected costs of generating electricity 2015 edition: Executive summary. Paris: IEA/Nuclear Energy Agency.

INA (Institut national de l'audiovisual), 1975. Debat sur l'implantation des centrales nucléaires au conseil regional. 13 February.

INA (Institut national de l'audiovisual), 2011. La France et le choix du nucléaire. 16 March. fresques.ina.fr/jalons/fiche-media/InaEdu05226 /la-france-et-le-choix-du-nucleaire.html (accessed 1 February 2017).

International Panel on Fissile Materials, 2015. Global fissile material report 2015: Nuclear weapon and fissile material stockpiles and production. Princeton, NJ: International Panel on Fissile Materials, Program on Science and Global Security, Princeton University.

Ipsos, 2011. Global citizen reaction to the Fukushima nuclear plant disaster. June. www.ipsos.com/sites/default/files/migrations/enuk/files/Assets/Docs/Polls/ipsos-global-advisor-nuclear-powerjune-2011.pdf (accessed 7 September 2017).

Le Monde, 2015. Un campement contre la poubelle nucleaire. 4 August.

Le Monde, 2016. EDF refuse d'enclencher la fermeture de la centrale nucléaire de Fessenheim. 15 June.

Macron, Emmanuel, 2017. Programme: En Marche! en-marche.fr/ emmanuel-macron/le-programme (accessed 26 June 2017). 
Mancini, Mauro, 2015. The divergence between actual and estimated costs in large industrial and infrastructure projects: Is nuclear special? In Nuclear New Build: Insights into Financing and Project Management, 177-88. Paris: Organisation for Economic Co-operation and Development and Nuclear Energy Agency.

Ministère du Developpement Durable, 2012. Résultat des stress tests concernant les installations nucléaires. Press release, 1 October.

Morice, Louis, 2011. Tchernobyl: Quand le nuage s'est (presque) arrete a la frontiere. Le Nouvel Observateur, 7 September. tempsreel. nouvelobs.com/planete/20110907.OBS9926/tchernobyl-quand-lenuage-s-est-presque-arrete-a-la-frontiere.html (accessed 7 September 2017).

PricewaterhouseCoopers Advisory, 2011. Le poids socio-économique de l'électronucléaire en France. May.

Radio Free Asia, 2016. Safety fears cause concern amid delays to China's Taishan nuclear plant. 7 March. www.rfa.org/english/news/china/ safety-03072016114147.html (accessed 1 February 2017).

Reuss, Paul, 2007. L'épopée de l'énergie nucléaire: une histoire scientifique et industrielle. Paris: EDP Sciences.

Roussely, François, 2010. Avenir de la filiere française du nucleaire civil: Synthèse du rapport. 16 June.

RTE (Réseau de transport d'électricité), 2016. Bilan électrique 2015. Paris: RTE.

Schlömer S., T. Bruckner, L. Fulton, E. Hertwich, A. McKinnon, D. Perczyk, J. Roy, R. Schaeffer, R. Sims, P. Smith, and R. Wiser, 2014. Annex III: Technology-specific cost and performance parameters. In Climate Change 2014: Mitigation of Climate Change. Contribution of Working Group III to the Fifth Assessment Report of the Intergovernmental Panel on Climate Change, edited by O. Edenhofer, R. Pichs-Madruga, Y. Sokona, E. Farahani, S. Kadner, K. Seyboth, A. Adler, I. Baum, S. Brunner, P. Eickemeier, B. Kriemann, J. Savolainen, S. Schlömer, C. von Stechow, T. Zwickel, and J. C. Minx, 1329-56. Cambridge: Cambridge University Press. 
Schneider, Mycle, and Antony Froggatt, with Julie Hazemann, Todahiro Katsuta, M. V. Ramana, and Steve Thomas, 2015. The World Nuclear Industry Status Report 2015. Paris: Mycle Schneider Consulting Project.

Schneider, Mycle, and Antony Froggatt, with Julie Hazemann, Ian Fairlie, Tadahiro Katsuta, Fulcieri Maltini, and M. V. Ramana, 2016. The World Nuclear Industry Status Report 2016. Paris: Mycle Schneider Consulting Project.

Schneider, Mycle, and Yves Marignac, 2008. Spent fuel reprocesssing in France. Research Report No. 4. Princeton, NJ: International Panel on Fissile Materials, Program on Science and Global Security, Princeton University.

Soleymieux, Loïc, 2015. EPR de Flamanville: De plus en plus en retard, de plus en plus coûteux. Le Monde, 21 April.

Stothard, Michael, 2017. Green activist and minister Nicolas Hulot to test Macron over energy. Financial Times, 19 May.

Taylor, Simon, 2016. The Fall and Rise of Nuclear Power in Britain: A History. Cambridge: UIT Cambridge.

Topçu, Sezin, 2013. La France nucléaire: l'art de gouverner une technologie contestée. Paris: Ed. du Seuil. doi.org/10.14375/NP.9782021052701

Vie Publique, 2012. Débat télévisé entre MM. Nicolas Sarkozy, président la République et François Hololande, député PS, candidates à l'élection présidentielle 2012, le 2 mai 2012, sur les projets et propositions des deux candidats et sur le bilan du président sortant. discours.viepublique.fr/notices/123000884.html (accessed 9 February 2017). 
This text is taken from Learning from Fukushima: Nuclear power in East Asia, edited by Peter Van Ness and Mel Gurtov, published 2017 by ANU Press, The Australian National University, Canberra, Australia.

dx.doi.org/10.22459/LF.09.2017.02 